\author{
Jan Macuda*, Jerzy Gasiński**, \\ Janusz Grad**, Sławomir Szewczyk**
}

\title{
AUXILIARY GRAVITY DRAIN AND INFILTRATION WELLS SUPPORTING BASIC DRAINAGE SYSTEM IN THE "BELCHATÓW" LIGNITE MINE***
}

\section{AN OUTLINE OF GEOLOGICAL AND HYDROGEOLOGICAL CONDITIONS IN THE AREA OF THE "BELCHATÓW" LIGNITE FIELD}

The "Bełchatów" lignite field is deposited in the Kleszczów Trough, which is a narrow WE- oriented tectonic structure formed in the Mesozoic basement and constituting its local deepening. The trough is about $38.5 \mathrm{~km}$ long, and $1.5-2.0 \mathrm{~km}$ wide $[1,2]$. Its natural division into of the "Bełchatów" field and "Szczerców" field stems from the presences of a small "Dębina" salt dome in its central part, being a locally elevated Permian salt deposit. In the geological build of the area participate strata of the Permian, Triassic, Jurassic, Cretaceous, Tertiary and Quaternary age. Groundwater in that area forms a complex of overburden, sub-coal and Mesozoic aquifers having numerous, well developed hydraulic contacts. The Mesozoic water-bearing complex is made up of fissured limestones, marls and breccia, whereas the overburden and sub-coal strata are mainly built of various types of sands, gravels and sand-and-gravel mix [3]. The generalized geological cross-section of "Bełchatów" Lignite Mine is presented in Figure 1.

\footnotetext{
* AGH University of Science and Technology, Faculty of Drilling, Oil and Gas, Krakow, Poland

** PGE Górnictwo i Energetyka Konwencjonalna S.A. Oddział KWB Bełchatów, Poland

*** Work performed within the statutory research program of AGH no. 11.11.190.555
} 


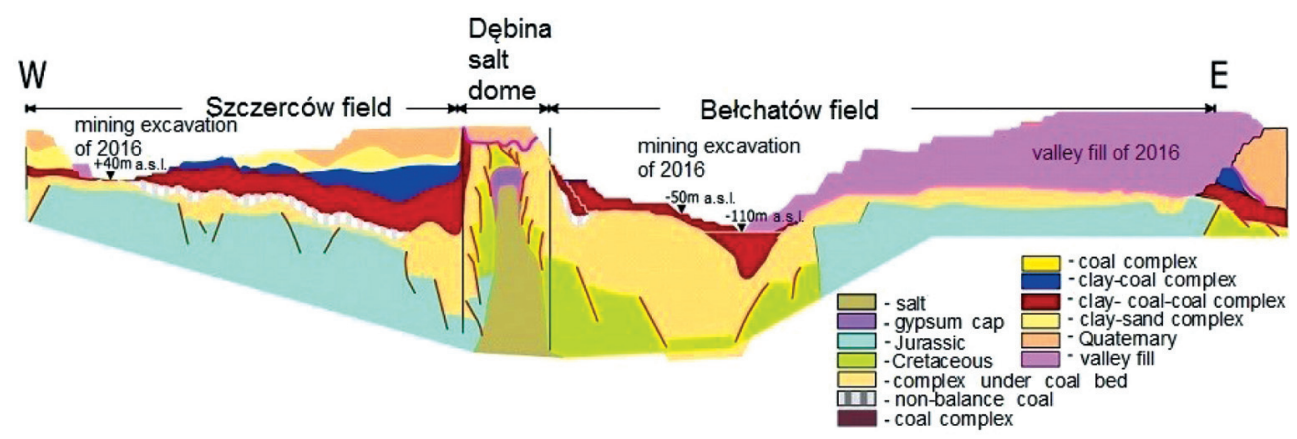

Fig. 1. Geological cross-section (WE) through "Bełchatów" lignite deposit [7]

\section{DEWATERING SYSTEM \\ IN "BELCHATÓW" LIGNITE MINE - PRIMARY AND AUXILIARY MINE DEWATERING SYSTEM}

The rock mass of the "Bełchatów" Lignite Mine is dewatered both in "Bełchatów" and "Szczerców" fields through the primary and auxiliary deep dewatering systems. The primary deep dewatering system consists of large diameter dewatering wells drilled from the surface to about 40 to $350 \mathrm{~m}$ of depth. These wells are distributed in the "barriers", i.e. along WE lines, parallel to the edge of the planned and existing excavation walls, at a distance of $80-150 \mathrm{~m}[3,5]$.

The auxiliary system is made of wells which support the primary system. These are:

- Large diameter gravity drain and pumping wells for sub-coal beds; they are to relieve stress in the aquifer under the coal seam and safely lower the water table below the lowermost extraction level.

- Shallow gravity drain (GD) wells and gravity infiltration (GI) wells for overburden horizons; their task is to remove residual and suspended waters, which were not drained by the primary system due to the complex geological build and disturbed system of layers.

The exploitation of deep large diameter wells of the primary and auxiliary system is efficient and allows for safe coal extraction. However, primary or secondary watering of overburden extraction benches can locally create hazard. This can be caused by [8,9]:

- Groundwaters in extensive erosion trough filled with permeable material, synclines, structural and tectonic troughs.

- Groundwaters present in closed, isolated lenses and disturbed sand layers within the impermeable series.

- Groundwaters suspended in the roof of impermeable series, in the area of small deleveling of top of these layers. 
The primary character of watering is observed in areas where watered sandy structures were not drilled and drained, or were not drained to the bottom through the deep wells of the primary system. The secondary watering takes place as a result of idleness of the well, especially when the a group of wells are excluded from production for a long time or the water-bearing layers opened by extraction were infiltrated by rainwater; another factor is the non-intaken water flows from extraction sites. Such waters may significantly affect the efficiency of major machines and have a negative impact on the work conditions (machining, transportation and stacking of overburden masses); in specific cases they may create water hazard. These outflows may be rapid, short-term or zonal and slow; they appear when performing mining operations [3, 6, 7].

\section{PLANNING SHALLOW GRAVITY DRAIN (GD) AND GRAVITY INFILTRATION (GI) WELLS OF THE AUXIALIARY DEWATERING SYSTEM}

One of the most important tasks of dewatering and for maintaining the stability of all slopes is to limit and eliminate the residual water quantity in the excavations. For doing so, shallow auxiliary gravity drain GD and gravity infiltration GI wells are drilled to about $30 \mathrm{~m}$ of depth (i.e. height of one excavator level in "Bełchatów" field and in "Szczerców" field, respectively [4, 7]. Prior to drilling these wells, the watering conditions have to be predicted and recognized, as on this basis the number, localization and depth of the wells to be performed in the excavations and their forefields can be planned. The predictions cover the evaluation of watering in particular excavation sites based on field observations of the excavator wall, hydrogeological measurements and analysis of all historical wellbores. As a result areas of potential watering, which require additional recognition and assumptions for precision drilling, are identified. The next step is recognition of watering through control wells. They are drilled with the "dry" rotary method and their task is to precisely define the lithology of the drilled layers (determine permeable and impermeable layers), depth of deposition of particular layers, localization of the water table, thickness and range of the watered zone. The results of test drilling are regularly analyzed by geological services and on this basis ways of limiting watering of the recognized hydrogeological structure are specified, e.g. shallow auxiliary dewatering GD and GI wells.

The gravity drain and infiltration wells are drilled from the surface in the forefield of the first extraction interval and in the extraction sites. Most of the tests are performed with the second group of wells. These wells drain water from primary and secondary watering zones. In most cases they pump and intake water from filtered layers below the static water level, and also gravity waters suspended in the roof of the onlying impervious layers. Sporadically they are drilled as gravity infiltration wells, which remove water from the higher water-bearing layers to the lower ones. By definition the life of such wells is 
short as residual waters are intaken from limited aquifers, which usually were drained by the primary dewatering system. Wells are exploited continuously or periodically, depending on local resources of groundwater and their recharging potential in the course of infiltration of rainwaters or non-intaken leaks from the excavation. Besides the wells are drilled directly in the forefield of the mining front and frequently are liquidated after a few weeks or months. They are emergency solutions used to locally fight water hazard.

\section{TECHNOLOGY OF DRILLING GRAVITY INFILTRATION (GI) AND GRAVITY DRAIN (GD) WELLS}

GI and GD wells are drilled with the "dry" method with a bailer or cutter bit, most frequently 298/360 mm in diameter, casing $\varnothing 419 \mathrm{~mm}$, though in some cases with a bailer/bit of $298 / 370 \mathrm{~mm}$ in diameter, casing $\varnothing 406 \mathrm{~m}$ or $430 / 480 \mathrm{~mm}$, casing $\varnothing 508 \mathrm{~mm}$. GD and GI wells were drilled with rigs H4-1H, Nordmeyer DSB 2/10 and Nordmeyer DSB 3/14. The "dry" rotary drilling technology with casing allows for taking samples in natural watering condition, guaranteeing proper identification of water-bearing levels to be filtered. In thus prepared wells steel filter columns $273 \mathrm{~mm}$ in diameter are installed. The active part of the filter column consists of grid filters placed in watered intervals, most frequently they are $1.7 \mathrm{~m}$ to $3.7 \mathrm{~m}$ long. After introducing filters GI and GD wells are activated with airlift. Then are installed pump aggregates with parameters corresponding to the abundance of the intaken aquifers and expected yield of the well. Pumped waters are transmitted through the pipelines to the nearest receivers on the surface of the excavation of its forefield. Exemplary filtering of GI well is presented in Figure 2.

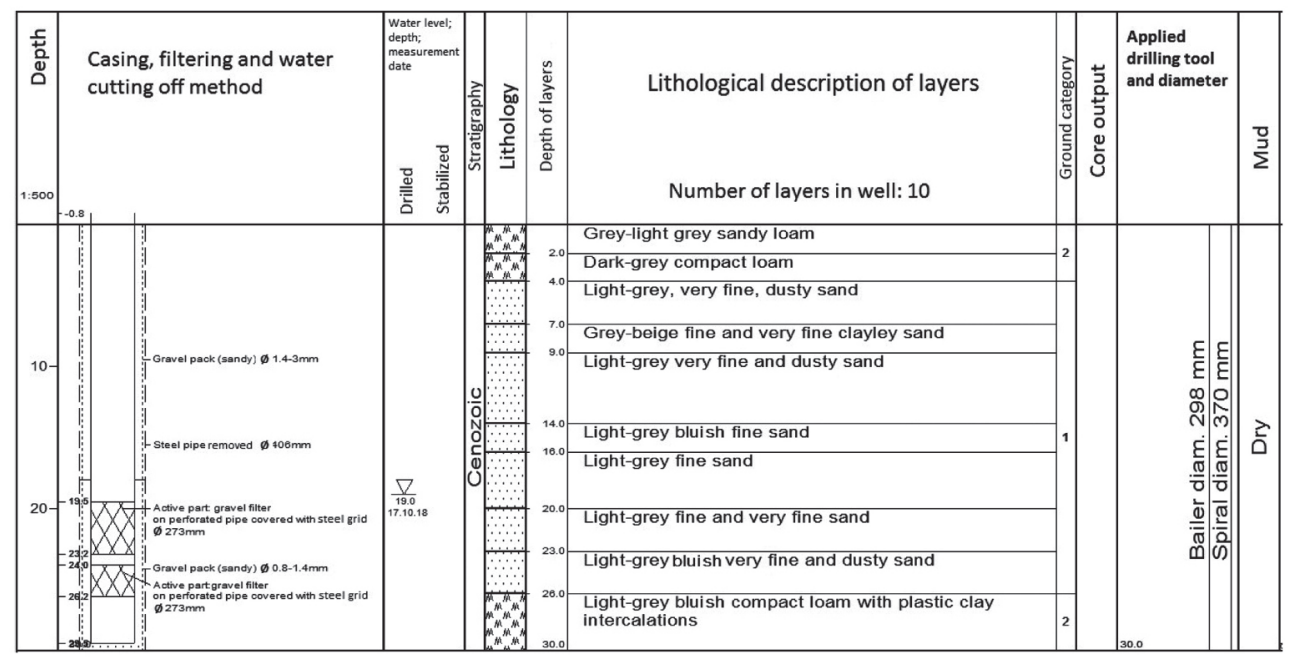

Fig. 2. Exemplary variant of filtering GI well with lithological profile 


\section{APPLICATION OF GRAVITY DRAIN (GD) AND GRAVITY INFILTRATION (GI) WELLS IN THE DEWATERING SYSTEM OF "BELCHATÓW" LIGNITE MINE}

The gravity drain and gravity infiltration wells have been drilled in the "Bełchatów" Lignite Mine since the beginning of mining works, i.e. for about 40 years. By the year 2015 20 to $40 \mathrm{GD}$ and GI wells had been realized depending on needs, then their number considerably decreased. This was partly connected with the draining wells introduced to industrial practice in 2015. They are filled with filtration material and in this way play the role of gravity drains. Such wells, drilled in the immediate forefield of mining works, support the deep dewatering system. They allow for gravity removal of waters suspended and accumulated in local delevelings of the roof of impermeable top of overburden to the lower waterbearing horizons, which are under control of the primary system wells. Drain wells considerably contribute to the removal of residual waters, simultaneously lowering the demand for emergency shallow wells of the auxiliary system. The gravity drain and gravity infiltration wells (with their length) realized in the years 2008 to 2017 are presented in Table 1.

Table 1

List of gravity drain and gravity infiltration wells in "Bełchatów" Lignite Mine in 2008-2017

\begin{tabular}{|c|c|c|c|c|c|}
\hline \multirow{2}{*}{ No. } & \multirow{2}{*}{ Year } & \multicolumn{2}{|c|}{ "Bełchatów" field } & \multicolumn{2}{c|}{ "Szczerców” field } \\
\cline { 3 - 6 } & & $\begin{array}{c}\text { Number } \\
\text { of drilled GD wells }\end{array}$ & $\begin{array}{c}\text { Total length } \\
{[\mathrm{m}]}\end{array}$ & $\begin{array}{c}\text { Number } \\
\text { of drilled GI wells }\end{array}$ & $\begin{array}{c}\text { Total length } \\
{[\mathrm{m}]}\end{array}$ \\
\hline 1 & 2008 & 33 & 719.0 & 54 & 1310.0 \\
\hline 2 & 2009 & 11 & 200.0 & 20 & 321.0 \\
\hline 3 & 2010 & 16 & 397.0 & 17 & 440.0 \\
\hline 4 & 2011 & 0 & 0.0 & 74 & 1633.0 \\
\hline 5 & 2012 & 0 & 0.0 & 74 & 1720.0 \\
\hline 6 & 2013 & 3 & 47.0 & 75 & 1880.0 \\
\hline 7 & 2014 & 27 & 607.0 & 122 & 3207.0 \\
\hline 8 & 2015 & 17 & 553.0 & 106 & 2416.0 \\
\hline 9 & 2016 & 4 & 121.0 & 31 & 943.0 \\
\hline 10 & 2017 & 5 & 166.0 & 36 & 985.0 \\
\hline
\end{tabular}

At present the gravity drain and gravity infiltration wells are mainly realized in the "Szczerców" field. This is connected with a big scope of works connected with the removal of the overburden and development of the opencast in the east direction. This causes that the GI wells are performed zonally in the excavation areas. Moreover 
the degree of rock mass dewatering did not reach the expected level. A different situation is encountered in the "Bełchatów" field, where the rock mass has been dewatered with a deep dewatering system for over 20 years, and where the rock mass was almost completely dewatered to the required datum. GD well are drilled only in relation to the local anomalies of water table or in places where suspended waters from rainwater infiltrations accumulate.

The efficiency of particular GD and GI wells drilled in the years 2013-2017 total to $0.05 \mathrm{~m}^{3} / \mathrm{min}$ to ca. $0.3 \mathrm{~m}^{3} / \mathrm{min}$. For comparison's sake, the output of single large diameter wells of the primary and auxiliary dewatering system is usually ca. $0.1 \mathrm{~m}^{3} / \mathrm{min}$ to ca. $4.0 \mathrm{~m}^{3} / \mathrm{min}$. On the example of data of 2017 (Tab. 2 and 3) the participation of gravity drain (GD) and gravity infiltration (GI) wells in the deep dewatering system was illustrated. The unit yield and percent participation of GD and GI wells in the total amount of pumped water by all active wells is seemingly low, almost marginal as compared to the output of all deep dewatering system. However the local role of shallow auxiliary wells is invaluable.

Table 2

Participation of gravity drain and gravity infiltration wells in deep dewatering system of the "Bełchatów" field in 2017

\begin{tabular}{|c|c|c|c|c|c|c|}
\hline Month & $\begin{array}{c}\text { Monthly } \\
\text { amount } \\
\text { of pumped } \\
\text { water from } \\
\text { GD well } \\
{\left[\mathrm{m}^{3}\right]}\end{array}$ & $\begin{array}{c}\text { Monthly } \\
\text { amount of } \\
\text { pumped water } \\
\text { from all active } \\
\text { wells } \\
{\left[\mathrm{m}^{3}\right]}\end{array}$ & $\begin{array}{c}\text { Participation } \\
\text { of GD wells } \\
\text { in total amount } \\
\text { of pumped } \\
\text { water } \\
{[\%]}\end{array}$ & $\begin{array}{c}\text { Number } \\
\text { of active } \\
\text { GD wells }\end{array}$ & $\begin{array}{c}\text { Number } \\
\text { of all active } \\
\text { wells }\end{array}$ & $\begin{array}{c}\text { Participation } \\
\text { of GD wells } \\
\text { in total number } \\
\text { of active wells } \\
{[\%]}\end{array}$ \\
\hline I & 21053 & 7623795 & 0.28 & 5 & 214 & 2.34 \\
\hline II & 18458 & 6707865 & 0.28 & 2 & 212 & 0.94 \\
\hline III & 24135 & 7657187 & 0.32 & 2 & 211 & 0.95 \\
\hline IV & 25057 & 7335900 & 0.34 & 2 & 211 & 0.95 \\
\hline V & 26164 & 7584141 & 0.34 & 1 & 213 & 0.47 \\
\hline VI & 27325 & 7269182 & 0.38 & 2 & 209 & 0.96 \\
\hline VII & 30541 & 7567718 & 0.40 & 4 & 212 & 1.89 \\
\hline VIII & 28078 & 7604168 & 0.37 & 4 & 206 & 1.94 \\
\hline IX & 27683 & 7203336 & 0.38 & 3 & 202 & 1.49 \\
\hline X & 29497 & 7335532 & 0.40 & 4 & 200 & 2.00 \\
\hline XI & 27606 & 6968335 & 0.40 & 4 & 203 & 1.97 \\
\hline XII & 26538 & 7351736 & 0.36 & 3 & 208 & 1.44 \\
\hline Total: & $\mathbf{3 1 2} \mathbf{1 3 5}$ & $\mathbf{8 8 2 0 8 ~ 8 9 5}$ & $\mathbf{0 . 3 5}$ & $\mathbf{3 6}$ & $\mathbf{2 5 0 1}$ & $\mathbf{1 . 4 3}$ \\
\hline
\end{tabular}


Table 3

Participation of gravity drain and gravity infiltration wells in deep dewatering system of the "Szczerców" field in 2017

\begin{tabular}{|c|c|c|c|c|c|c|}
\hline Month & $\begin{array}{c}\text { Monthly } \\
\text { amount } \\
\text { of pumped } \\
\text { water } \\
\text { from GI well } \\
{\left[\mathrm{m}^{3}\right]}\end{array}$ & $\begin{array}{c}\text { Monthly } \\
\text { amount } \\
\text { of pumped } \\
\text { water from all } \\
\text { active wells } \\
{\left[\mathrm{m}^{3}\right]}\end{array}$ & $\begin{array}{c}\text { Participation } \\
\text { of GI wells } \\
\text { in total amount } \\
\text { of pumped } \\
\text { water } \\
{[\%]}\end{array}$ & $\begin{array}{c}\text { Number } \\
\text { of active GI } \\
\text { wells }\end{array}$ & $\begin{array}{c}\text { Number } \\
\text { of all active } \\
\text { wells }\end{array}$ & $\begin{array}{c}\text { Participation } \\
\text { of GI wells } \\
\text { in total number } \\
\text { of active wells } \\
{[\%]}\end{array}$ \\
\hline I & 22252 & 8632816 & 0.26 & 9 & 342 & 2.63 \\
\hline II & 23053 & 7754450 & 0.30 & 14 & 367 & 3.81 \\
\hline III & 35369 & 8283509 & 0.43 & 17 & 371 & 4.58 \\
\hline IV & 50124 & 8018799 & 0.63 & 16 & 375 & 4.27 \\
\hline V & 71796 & 8158542 & 0.88 & 14 & 364 & 3.85 \\
\hline VI & 65172 & 7492433 & 0.87 & 18 & 370 & 4.86 \\
\hline VII & 83073 & 7689610 & 1.08 & 22 & 375 & 5.87 \\
\hline VIII & 87286 & 7823769 & 1.12 & 20 & 366 & 5.46 \\
\hline IX & 44519 & 7476807 & 0.60 & 21 & 379 & 5.54 \\
\hline X & 79999 & 7586669 & 1.05 & 21 & 369 & 5.69 \\
\hline XI & 88735 & 7190284 & 1.23 & 21 & 359 & 5.85 \\
\hline XII & 86364 & 7634984 & 1.13 & 20 & 359 & 5.57 \\
\hline Total: & $\mathbf{7 3 7 7 4 2}$ & $\mathbf{9 3 7 4 2 ~ 6 7 2}$ & $\mathbf{0 . 7 9}$ & $\mathbf{2 1 3}$ & $\mathbf{4 3 9 6}$ & $\mathbf{4 . 8 4}$ \\
\hline
\end{tabular}

\section{RESULTS OF OPERATION \\ OF SHALLOW AUXILIARY DEWATERING SYSTEM OF OVERBURDEN EXTRACTION LEVELS}

Despite their low participation in the deep dewatering system, the gravity drain and gravity infiltration wells significantly influence its efficiency and effectiveness. They are realized in relation to the current demand defined on the basis of evaluation of the primary and auxiliary watering of the overburden. Their realization is operative, which brings about the quick liquidation of the existing watering in the overburden. Thanks to this the required degree of consistency of mined masses, which have to be safely hauled to the external stacking site is reached. They also significantly improve the work conditions, and the stacking site is formed in a way providing safety and stability to the excavator walls. Thanks to the operation of GD and GI wells local water outflows from active 
excavations creating hazard to the operation of the machines and the hauling system are liquidated. The operation of GD and GI wells supplements the deep dewatering system and eliminates the hazard created by residual waters.

\section{FINAL REMARKS}

The designing, drilling and exploitation of gravity drain and gravity infiltration wells have been verified, optimized and realized in practice for years with better and better results. The present state of the art and experience in this subject are a result of over 40 years of engineer's practice in the development and exploitation of the "Bełchatów" lignite field. Thanks to the help of mine services the wells are drilled quickly, almost immediately after the watering of the overburden in the forefield of the mining front is identified. This makes the whole system of shallow auxiliary GD and GI wells very efficient and effective when emergency removal of residual waters is involved. Undoubtedly drain wells realized in the forefield of the advancing front play an important role in the liquidation of primary and secondary watering caused by suspended and residual waters. Starting from the implementation of such wells in 2015, the need to liquidate overburden watering of extraction sites and the forefield is observed to decrease, and thus the number of drilled gravity drain and gravity infiltration wells has been optimized. The works on the recognition of watering and drilling of such wells are currently conducted providing efficient intakes of non-drained waters from the mining forefield.

\section{REFERENCES}

[1] Gasiński J., Macuda J., Szewczyk S.: Drainage Wells as an Integral Part of a Deep Dewatering System in Szczerców Field in the Bełchatów Lignite Mine. AGH Drilling, Oil, Gas, vol. 34, no. 2, 2017, pp. 455-463.

[2] Hydrogeologiczne warunki odwadniania złoża węgla brunatnego Bełchatów - etap'18 wraz z analiza robót wiertniczych za okres 1.01.2016. do 31.12.2016. - Pole Betchatów i Pole Szczerców. Oprac. Poltegor - Projekt Sp. z o.o., Wrocław 2017.

[3] Kuszneruk J., Wojtkowiak B.: Ocena efektywności odwadniana złoża węgla brunatnego - Pole Bełchatów - systemem wielkośrednicowych studni głębinowych w poszczególnych okresach funkcjonowania kopalni. Sympozjum Naukowe: 25 lat doświadczeń KWB „Bełchatów”, 2000.

[4] Karty otworów hydrogeologicznych wykonywanych w KWB „Bełchatów”. 
[5] Macuda J., Gasiński J., Krokosz J.: Technologia wiercenia głębokich studni odwadniających na przykładzie wierceń realizowanych $w$ obrębie wysadu solnego „Dębina”. Oficyna Wydawnicza Politechniki Wrocławskiej, Prace Naukowe Instytutu Górnictwa Politechniki Wrocławskiej, z. 112, Seria: Konferencje, 44/2005.

[6] Macuda J. et al.: Opracowanie techniki i technologii prowadzenia wierceń $w$ warunkach utworów skrasowiatych i silnego krasu na Polu Szczerców. Wydział Wiertnictwa, Nafty i Gazu AGH, Kraków 2010 [unpublished].

[7] Materiały ze zbiorów archiwalnych KWB „Bełchatów”.

[8] Pole Betchatów i Pole Szczerców. Ocena wyprzedzenia robót górniczych i robotami odwodnieniowymi dla Pola Betchatów i Pola Szczerców - warunki bieżace, określenie parametrów na przysztość. Oprac. Poltegor - Projekt Sp. z o.o., Wrocław 2007.

[9] Pole Szczerców. Otwory drenażowe - etap'17. Oprac. Poltegor - Projekt Sp. z o.o., Wrocław 2016. 